\title{
Partisipasi Masyarakat Dalam Program Sedekah Sampah Di Masjid Raudatul Jannah Yayasan Khairu Ummah Makassar
}

\author{
Community Participation in the Waste Alms Program at the Raudatul Jannah Mosque, \\ Khairu Ummah Foundation, Makassar
}

\author{
Andi Zulfikar Syaiful ${ }^{1 *}$, Muh. Fikruddin B. Abd. H. ${ }^{2}$, Jumadil ${ }^{2}$, Djusdil Akrim², \\ Nani Anggraini ${ }^{2}$ \\ *Email: syaifulzulfikar@yahoo.com \\ ${ }^{1}$ Program Studi Teknik Kimia, Fakultas Teknik, Universitas Bosowa \\ ${ }^{2}$ Program Studi Teknik Lingkungan, Fakultas Teknik, Universitas Bosowa
}

Diterima: 10 April 2021 / Disetujui: 20 Agustus 2021

\begin{abstract}
ABSTRAK
Sedekah Sampah adalah salah satu bentuk pengelolaan sampah partisipatif menggunakan pendekatan keagamaan. Kegiatan ini dilakukan telah dilakukan oleh Pengurus Masjid Raudatul Jannah Yayasan Khairu Ummah Makassar secara rutin dua kali sebulan sejak Maret 2021. Sedekah sampah telah memberikan manfaat secara ekonomi, sosial, dan lingkungan, yaitu selain mereduksi volume sampah yang diangkut ke Tempat Pembuangan Akhir (TPA), hasil penjualan sampah telah digunakan untuk kegiatan sosial kemasyarakatan. Namun kegiatan ini masih menghadapi masalah, yaitu rendahnya partisipasi masyarakat (hanya sekitar 20\%). Tulisan ini bertujuan untuk menganalisis faktor penyebab rendahnya partisipasi masyarakat dalam kegiatan sedekah sampah. Jenis penelitian ini adalah kualitatif-deskriptif, pengumpulan data penelitian dilakukan dengan menggunakan teknik wawancara, observasi dan dokumentasi. Berdasarkan wawancara dan observasi yang dilakukan, sebagian besar masyarakat telah memiliki pengetahuan dan sikap yang baik tentang pentingnya kebersihan lingkungan. Namun pengetahuan dan sikap masyarakat masih rendah terkait metode 3R (Reduce, Reuse, Recycle), dan program sedekah sampah. Perbaikan fasilitas dan peningkatan keterlibatan tokoh masyarakat dalam mensosialisasikan dan memfasilitasi pelaksanaan program sedekah sampah adalah dua hal yang perlu dilakukan. Usaha untuk meningkatkan manfaat sedekah sampah secara ekonomi, sosial, dan lingkungan kepada masyarakat perlu dilanjutkan agar masyarakat yang telah merasakan manfaatnya akan mengikuti program ini dengan sukarela
\end{abstract}

Kata Kunci: Sedekah, Sampah, Masyarakat, Masjid, Makassar

\section{ABSTRACT}

Waste sadaqah is a form of participatory waste management using a religious approach. This activity is carried out by the Raudatul Jannah Mosque Management, Yayasan Khairu Ummah Makassar, regularly. twice a month since March 2021. Waste sadaqah has provided economic, social and environmental benefits. In addition to reducing the amount of waste transported to the waste landfill site (TPA), the financial profits from the sale of waste had used for social activities. However, this activity still faces problems. The low level of community participation (only about 20\%) is the main problem. The aim of this research is to analyze factors that influence the low level of community participation in Waste Sadaqah activities. This research is qualitative-descriptive research. Data collection is carried out using interview, observation and documentation techniques. Based on interviews and observations conducted, most of the people already have good knowledge and attitudes about the importance of environmental cleanliness; but low in term of the $3 R$ (Reduce, Reuse, Recycle) method and the waste sadaqah program. Improvement of facilities and increasing involvement of community leaders in socializing and facilitating the implementation of the waste sadaqah program are two things that need to be done. Efforts to increase the economic, social and environmental benefits of waste sadaqah to 
the community need to be continued so that people who have felt the benefits will participate in this program voluntarily.

Keywords: Alms, Garbage, Society, Mosque, Makassar

\section{A. PENDAHULUAN}

Persoalan besar yang menjadi masalah di hampir semua wilayah adalah masalah sampah. Dinas Lingkungan Hidup kota makassar mencatat, volume sampah yang masuk ke Tempat Pembuangan Akhir (TPA) di Jalan Tamangapa Antang, Kecamatan Manggala mencapai 900 ton per harinya. Sampah ini berasal dari 1,6 juta warga Makassar (Suarasulsel, 2021). Volume sampah yang kian bertambah akibat meningkatnya volume sampah rumah tangga yang tidak diikuti oleh pengelolaan yang tepat adalah faktor utama yang menyebabkan hal tersebut. UPTD TPA yang umumnya sudah beroperasi puluhan tahun dengan armada angkut dan peralatan yang terbatas menyebabkan sebagian besar sampah dibiarkan menggunung. Sampah plastik menjadi masalah utama karena Indonesia merupakan negara nomor dua penyumbang sampah laut terbesar di dunia dan pembuang sampah organik terbesar dunia setelah Arab Saudi. Sampah mikroplastik yang dibuang ke sungai akan tergerus menjadi nanoplastik yang akan mencemari perairan laut yang nantinya mencemari ikan dan juga garam (Republika, 2021). Diperkirakan jumlah sampah plastik yang masuk ke lautan yang masuk ke laut pada 2020 mencapai sekitar 521.540 ton (Antaranews, 2021).

Pengelolaan Sampah Partisipatif adalah solusi untuk menangani sampah mulai dari sumbernya (Ismoyo, 2015). Namun yang menjadi kesulitan adalah bagaimana menarik minat masyarakat untuk ikut mengelola sampah menjadi sesuatu yang bermanfaat. Berbagai inovasi telah dikembangkan untuk menarik minat masyarakat berpartipasi dalam pengelolaan sampah, misalnya bank sampah, berobat ke poliklinik dengan bayaran sampah, beli pulsa dengan sampah, atau warung gratis bayar pakai sampah. Pengelolaan sampah partisipatif pada dasarnya bertujuan untuk mengurangi beban TPA dan meminimalisasi dampak buruk akibat menumpuknya sampah di mana-mana.

Ada beberapa program pemerintah kota Makassar untuk menanggulangi sampah yaitu LISA (Lihat Sampah Ambil), MABELO (Makassar Bersih 
Lorong), MABASA (Makassar Bebas Sampah) dan Aku dan Sekolahku Tidak Rantasa. Ke empat jargon ini digunakan oleh Pemerintah Kota Makassar dalam merubah pola pikir masyarakat untuk cinta kerbersihan. Program tersebut dikemas secara satu kesatuan dalam Gerakan Makassarta tidak Rantasa'. Akan tetapi perubahaan sikap masyarakat belum maksimal dan komitmen sikap terhadap kebersihan lingkungan masih perlu ditingkatkan (Yamin, 2019).

Salah satu pendekatan lain yang dapat dilakukan untuk mengubah perilaku masyarakat adalah melalui pendekatan keagamaan. Pendekatan keagamaan sangat penting untuk meningkatkan kesadaran masyarakat mengelola sampah. Majelis Ulama Indonesia (MUI) telah mengeluarkan fatwa nomor 47/2014 tentang pengelolaan sampah yang menyebutkan bahwa setiap muslim wajib menjaga kebersihan lingkungan, memanfaatkan barang-barang gunaan untuk kemaslahatan. Selain itu menghindarkan diri dari perbuatan yang menyia-nyiakan barang/harta yang masih bisa dimanfaatkan menurut ketentuan syar'i ataupun kebiasaan umum di masyarakat dan yang berlebih-lebihan, yaitu penggunaan barang/harta melebihi kebutuhannya. Untuk mengurangi dampak buruk sampah, Sekretariat Tim Koordinasi Nasional Penanganan Sampah Laut (TKN PSL) bersama Deputi Bidang Koordinasi Pengelolaan Lingkungan dan Kehutanan Kementerian Koordinator Bidang Kemaritiman dan Investasi (Kemenko Marves), Kementerian Hidup dan Kehutanan (KLHK) serta Majelis Ulama Indonesia (MUI) mengusung Gerakan Sedekah Sampah Indonesia (GRADASI) berbasis masjid. Gerakan ini diluncurkan pada Jumat 30 April 2021 yang bertujuan untuk memperbaiki tata kelola sampah dan mengajak masyarakat serta komunitas agama untuk mengubah pandangan terkait sampah. Hal yang membedakan dengan konsep bank sampah adalah hasil penjualan sampah pada kegiatan sedekah sampah akan dikelola oleh masjid untuk berbagai kegiatan social keagamaan.

Sebelum kampanye GRADASI, Pengurus Masjid Raudatul Jannah Yayasan Khairu Ummah telah menjadikan Sedekah Sampah sebagai salah satu program unggulannya sejak Maret 2021. Kegiatan sedekah sampah di Masjid Raudatul Jannah rutin dilakukan dua kali sebulan baik secara mandiri oleh pengurus masjid maupun bekerja sama dengan Sekolah Dasar Islam Khairu Ummah yang lokasinya berada di lantai 
atas masjid. Pengurus masjid mengajak dan menghimbau masyarakat untuk memilah sampah bernilai ekonomi dari rumah dan kemudian disedekahkan ke pusat pengumpulan di masjid. Hasil sedekah sampah telah digunakan untuk kegiatan sosial kemasyarakatan terutama di masa pandemik Covid-19, antara lain bazaar sembako murah dan pemberian paket sembako gratis pada bulan Ramadhan $1442 \mathrm{H}$, bantuan pendidikan bagi siswa tidak mampu, serta bantuan pengobatan/ kedukaan bagi warga sekitar. Namun masih terdapat kendala pada pelaksanaannya terutama masih kurangnya warga masyarakat yang ikut berpartisipasi di dalam program tersebut. Tulisan ini bertujuan untuk menganalisis faktor penyebab rendahnya partisipasi masyarakat dalam kegiatan sedekah sampah. Hasilnya akan digunakan sebagai bahan penyusunan program yang lebih baik.

\section{B. METODE PENELITIAN}

Jenis penelitian ini adalah kualitatifdeskriptif yang bertujuan untuk mendeskripsikan partisipasi masyarakat di dalam pelaksanaan program sedekah sampah di Masjid Raudatul Jannah Yayasan Khairu Ummah, Perumahan Graha Janna Land 1, Makassar. Informan penelitian dipilih menggunakan teknik purposive sampling, terdiri dari berbagai unsur tokoh masyarakat dan jamaah masjid/ masyarakat di sekitar masjid. Pengumpulan data penelitian dilakukan dengan menggunakan teknik wawancara, observasi dan dokumentasi.

\section{HASIL DAN PEMBAHASAN}

\section{Alur Sedekah Sampah}

Berikut ini adalah alur pelaksanaan sedekah sampah yang telah dilakukan di Masjid Raudatul Jannah:

1) Warga membersihkan lingkungan rumahnya masing-masing, juga secara rutin mengumpulkan dan memilah sampah. Sampah telah dipilah sesuai jenis sejak dari rumah, misalnya dibagi 3 (tiga) jenis, kertas (K), Plastik (P), Kaca, Besi (KB).

2) Warga menyetorkan sampah baik diantar sendiri maupun dijemput relawan ke rumahnya, dengan menghubungi nomor telepon pengelola sedekah sampah.

3) Untuk sementara sampah dari warga dikumpulkan di halaman masjid Raudatul Jannah, sampai ditentukan tempat yang memadai guna memudahkan pemilahan sampah.

4) Sampah yang terkumpul kemudian dipilah sesuai dengan jenisnya, disatukan dalam wadah karung yang 
lebih besar. Sehingga ketika dijual sudah terpisah.

5) Sampah yang telah dipilah sesuai dengan jenisnya kemudian dijual kepada pengepul bank sampah. Bank Sampah yang telah menjadi mitra yaitu Bank Sampah Unit Lambert.

6) Setelah sampah dijual, uang hasil penjualan dikelola oleh bendahara masjid, dicatat dalam pembukuan, dan dikelola dengan amanah, dan jujur. Keuangan dilaporkan secara periodik, jumlah pemasukan dan pengeluarannya.

7) Dana yang tersimpan akan disalurkan melalui program yang sudah dirancang.

\section{Kesadaran Bersedekah Sampah}

Jamanti (2014) kesadaran lingkungan hidup dapat diukur dengan indicator pengetahuan, sikap, dan perilaku (tindakan). Pengetahuan lingkungan dapat diartikan sebagai suatu pengetahuan yang dimiliki seseorang sehingga ia mampu mengelola sumber daya alam dengan bijaksana, mampu mencegah, menganalisis dan menanggulangi dampak kegiatan berpikir, bersikap dan bertindaknya sebagai bentuk pembinaan terhadap lingkungan.
Bekal pengetahuan diperlukan dalam mempengaruhi perilaku pro-lingkungan masyarakat, tanpa pengetahuan, orang tidak akan punya alasan untuk apa perilaku pro-lingkungan mereka lakukan, dan bagaimana cara melakukannya. Minimal, masyarakat tahu tentang isu-isu lingkungan yang melanda bumi saat ini, masyarakat tahu tentang berbagai ancaman yang dihadapi oleh lingkungan saat ini. Disamping itu, masyarakat juga tahu apa yang harus dilakukan agar lingkungan tetap terjaga dan lestari. Hal ini penting sebab jangan sampai masyarakat hanya fokus pada menghindari ancaman dibandingkan dengan berbuat agar ancaman tidak berwujud atau berlanjut. Dengan pengetahuan yang cukup, masyarakat diharapkan bertindak pro aktif untuk menjaga dan melestarikannya. Menurut Hines, dkk. (1987), pengetahuan dapat menjadi prediktor yang handal terhadap perilaku lingkungan dan karenanya dapat dikatakan memiliki pengaruh yang dominan terhadap perilaku.

Berdasarkan wawancara dan observasi yang dilakukan, sebagian besar masyarakat yang berdomisili di sekitar masjid telah memiliki pengetahuan yang baik tentang pentingnya kebersihan lingkungan, sehingga sikap dan 
tindakannya juga baik yaitu mereka secara rutin membersihkan lingkungan sekitar rumahnya dan telah membuang sampah pada tempatnya untuk selanjutnya diangkut oleh armada sampah yang telah dilanggan. Akan tetapi, hanya sedikit masyarakat yang memiliki pengetahuan tentang metode 3R (Reduce, Reuse, Recycle), serta program bank sampah dan sedekah sampah, sehingga menyebabkan sedikit pula yang berperilaku baik untuk memilah sampahnya kemudian menyedekahkan sampah bernilai ekonomi. Dari sekitar seratus kepala keluarga (KK) di sekitar masjid, baru sekitar 20\% yang secara rutin menyumbangkan sampahnya. Pengetahuan yang minim mengenai produk apa saja yang masih memiliki nilai ekonomis dan dapat diikutkan pada proses 3R adalah salah satu kendalanya.

Ditinjau dari segi perannya, yang paling bertanggungjawab melakukan pembekalan pengetahuan adalah pemerintah, disusul lembaga-lembaga kemasyarakatan yang peduli lingkungan untuk memberikan pengetahuan mengenai lingkungan kepada masyarakat melalui berbagai media informasi yang tersedia. Disamping itu, perlu juga disosialisasikan berbagai regulasi yang berhubungan dengan pelestarian lingkungan, yang selama ini terasa masih kurang.

Terkait dengan program sedekah sampah, sosialisasinya masih sangat minim bahkan baru dicanangkan oleh MUI melalui program GRADASI pada awal tahun 2021. Pengurus Masjid Raudatul Jannah telah memberikan informasi tentang program tersebut kepada masyarakat, namun ketidaktepatan media dan metode yang dipilih untuk memberikan informasi kepada masyarakat menyebabkan hasilnya tidak sesuai dengan harapan. Selama masa pandemic Covid-19, informasi hanya dapat diberikan secara on line melalui pengiriman flyer ke grup whatsapp warga. Minimnya informasi yang dapat diberikan melalui pesan singkat menyebabkan sebagian besar pesan belum tersampaikan dengan baik. Penyuluhan yang diberikan seharusnya dapat membuat masyarakat paham mengenai metode $3 R$ terutama mengenai pentingnya dan bagaimana cara memilah sampah sebelum dibuang karena pengetahuan yang diberikan sangat penting dalam membentuk pola pikir rasional serta bertanggung jawab.

Menurut Hines, dkk. (1986) dalam Kollmus \& Agyeman (2002), orang yang memiliki sikap peduli lingkungan yang tinggi, lebih memungkinkan untuk 
bertindak pro-lingkungan. Berdasarkan observasi yang dilakukan, sebagian besar masyarakat setuju bahwa sampah yang tidak dipilah akan menyebabkan beban TPA yang sangat tinggi. Masyarakat juga bersikap kritis terhadap akibat yang ditimbulkan oleh penumpukan sampah di TPA, karena mereka telah mengalami gangguan asap akibat kebakaran TPA Tamangapa beberapa tahun lalu dan bau busuk pada musim penghujan yang sangat merugikan. Namun sikap yang ditunjukkan ternyata belum melahirkan tindakan yang diharapkan. Kesadaran masyarakat untuk ikut menyedekahkan sampahnya perlu dikaji lebih lanjut. Berdasarkan hasil wawancara, terdapat dua hal utama yang mempengaruhi keberhasilan kegiatan sedekah sampah, yaitu:

1. Fasilitas pengelolaan sampah di Masjid Raudatul Jannah,

2. Keterlibatan tokoh masyarakat dalam mensosialisasikan dan memfasilitasi pelaksanaan program sedekah sampah.

Tabel 1. Fasilitas Pengelolaan Sampah di Masjid Raudatul Jannah

\begin{tabular}{ll}
\hline \multicolumn{1}{c}{ Variabel } & \multicolumn{1}{c}{ Kondisi } \\
\hline $\begin{array}{l}\text { Ketersediaan tempat } \\
\text { dan kantung sampah }\end{array}$ & $\begin{array}{l}\text { Sangat baik. Jumlah tempat sampah yang disediakan sangat memadai dan telah } \\
\text { disediakan kantung-kantung sampah untuk sampah plastik dan kertas }\end{array}$ \\
\hline $\begin{array}{l}\text { Bahan pembuat } \\
\text { tempat sampah }\end{array}$ & $\begin{array}{l}\text { Sangat baik. Tempat sampah terbuat dari bahan yang kuat, tahan karat, } \\
\text { permukaan bagian dalam rata/licin. Tempat sampah dikosongkan setiap 1 x 24 } \\
\text { jam atau apabila 2/3 bagian telah terisi penuh. }\end{array}$ \\
\hline $\begin{array}{l}\text { Ketersediaan TPS } \\
\text { (tempat pembuangan }\end{array}$ & $\begin{array}{l}\text { Baik. TPS terbuat dari beton permanen berukuran besar sehingga mudah } \\
\text { dikosongkan. TPS terletak di lokasi yang mudah dijangkau kendaraan } \\
\text { sampah sementara) }\end{array}$ \\
$\begin{array}{l}\text { pengangkut sampah. Kondisi TPS baik tetapi tidak memiliki penutup sehingga } \\
\text { masih terkena hujan, memungkinkan dibongkar oleh binatang atau terbawa oleh } \\
\text { angin. }\end{array}$ \\
\hline $\begin{array}{l}\text { TPS dikosongkan setiap 2 x 24 jam. Sampah yang diangkut oleh kendaraan } \\
\text { pengangkut sampah adalah sampah sisa hasil pemilahan. Sampah yang masih } \\
\text { memiliki nilai ekonomis akan dijual ke bank sampah. }\end{array}$ \\
\hline
\end{tabular}

Tabel 2. Keterlibatan Tokoh Masyarakat dalam Mensosialisasikan dan Memfasilitasi Pelaksanaan Program Sedekah Sampah di Masjid Raudatul Jannah

\begin{tabular}{ll}
\hline Tokoh Masyarakat & \multicolumn{1}{c}{ Peran } \\
\hline Ketua RT & $\begin{array}{l}\text { Mendukung dan melakukan sosialisasi program sedekah sampah di grup- } \\
\text { grup whatsapp warga. Namun belum melakukan sinergi antara kegiatan } \\
\text { sedekah sampah dengan sistem persampahan warga }\end{array}$ \\
\hline Pengurus Yayasan & $\begin{array}{l}\text { Mendukung dan memfasilitasi program sedekah sampah di Masjid Raudatul } \\
\text { Khairu Ummah }\end{array}$ \\
\hline Kepala Sekolah dan & $\begin{array}{l}\text { Ikut berperan aktif dalam program sedekah sampah bersama pengurus } \\
\text { Guru Sekolah Dasar } \\
\text { Kslam Komite Sekolah dan Persatuan Orang Tua Murid dengan memberikan } \\
\text { Ummah Khairu }\end{array}$ \\
& $\begin{array}{l}\text { penyuluhan mengenai sedekah sampah melalui pengiriman flyer secara } \\
\text { daring ke grup-grup whatsapp orang tua siswa dan secara periodik } \\
\text { mengumpulkan sampah bernilai ekonomis dari sekolah dan orang tua siswa }\end{array}$ \\
\hline Tokoh Perempuan & melakukan sosialisasi pengelolaan sampah rumah tangga dan sedekah \\
\hline
\end{tabular}




\begin{tabular}{ll}
\hline & sampah ke grup-grup whatsapp warga \\
\hline Pengurus masjid & Menggagas dan menyelenggarakan program sedekah sampah secara rutin \\
& setiap 2 pekan. Mekanismenya adalah dengan cara mengumpulkan/ \\
& menjemput sampah terpilah dari rumah-rumah warga dan menjualnya ke \\
& bank sampah mitra. Sayangnya proses ini terkendala oleh belum tersedianya \\
& tempat khusus untuk mengumpulkan sampah, untuk sementara sampah \\
& dikumpulkan di halaman masjid atau rumah warga yang kosong \\
\hline Pemuda & peran pemuda dalam program sedekah sampah tidak memadai \\
\hline
\end{tabular}

Hasil wawancara tokoh-tokoh masyarakat menunjukkan bahwa kurangnya partisipasi masyarakat turut dipengaruhi oleh belum bersinerginya tokoh masyarakat tersebut dalam mendukung program sedekah sampah sehingga gaungnya lemah. Kegiatan yang dilakukan seolah-olah hanya kegiatan amal oleh pengurus masjid. Untuk periode selanjutnya perlu dilakukan pertemuan seluruh tokoh masyarakat untuk mensinergikan program sedekah sampah dengan program Kebersihan dan Kesehatan Lingkungan yang digagas di tingkat RT. Beberapa hal yang perlu dirumuskan di dalam pertemuan tokoh masyarakat adalah:

a. Membentuk organisasi sedekah sampah yang tertata dan secara komprehensif memuat setiap unsur yang ada di masyarakat, yaitu melibatkan ketua warga, ibu-ibu majelis taklim, tokoh pemuda, pengurus masjid dan yayasan, dan perwakilan dari warga,

b. Menyusun perencanaan program sedekah sampah dan meminta pendampingan pemerintah kota untuk memperbaiki program yang telah direncanakan.

c. Mengembangkan program yang telah ada menjadi program terpadu sesuai dengan kondisi masyarakat sasaran.

1) Menggerakkan jamaah masjid untuk ikut aktif di dalam kegiatan sedekah sampah dengan melakukan sosialisasi, kampanye,

pelatihan/pendidikan secara rutin pada kegiatan keagamaan,

2) Melibatkan secara aktif para security dan cleaning service diluar jam kerja resmi mereka sebagai relawan yang selanjutnya dapat diberi upah dari hasil penjualan sampah,

3) Pemberian berbagai apresiasi kepada anggota masyarakat seperti bantuan keselamatan dan kesehatan kerja, beasiswa untuk anak pengurus kelompok pengelola sampah, menjadi duta pengelolaan sampah dan 
sebagai nara sumber penyusunan peraturan terkait pengelolaan sampah.

4) Menjadikan program sedekah sampah sebagai bagian dari kegiatan ekstra kokurikuler siswa di tingkat PAUD, SD, dan SMP yang dibina secara kolaboratif dengan pihak sekolah.

d. Mengembangkan metode 3R. Tidak semua sampah dijual langsung di bank sampah, sebagian barang bekas yang terkumpul bisa dibuat menjadi kerajinan tangan atau produk bermanfaat lainnya. Produk ini dapat dijual atau dipakai di rumah tangga masing-masing.

\section{Meningkatkan kesadaran masyarakat untuk ikut berpartisipasi dalam program sedekah sampah}

Secara umum, masyarakat akan ikut secara sukarela dalam suatu program jika mereka merasakan manfaat dari kegiatan tersebut. Olehnya itu perlu dideskripsikan manfaat sedekah sampah dengan jelas untuk kemudian disosialisakan ke masyarakat.

a. Manfaat Ekonomi. Sampah yang telah terkumpul dapat dijual langsung atau diolah menjadi kerajian tangan yang memiliki nilai jual. Untuk meningkatkan manfaat ekonomi, perlu pendampingan dalam peningkatan pemasaran hasil pengolahan sampah.

b. Manfaat Sosial. Secara sosial hal ini bermanfaat menguatkan semangat dan partisipasi warga dalam mengelola sampah. Berbeda dengan bank sampah, hasil penjualan produk pada program sedekah sampah digolongkan sebagai donasi atau sedekah yang selama ini telah disalurkan kepada yang berhak, misalnya pemberian paket santunan sembako untuk fakir miskin, santunan beasiswa pendidikan anak yatim piatu dan dhuafa, dan santunan kesehatan bagi setiap warga kurang mampu dan lain-lain.

Manfaat Lingkungan yang dirasakan warga masyarakat merupakan pendorong utama pengelolaan sampah partisipatif. Secara keseluruhan, pengelolaan sampah partisipatif telah mampu mereduksi sampah di kawasan permukiman, mengurangi beban TPA dan meminimalisasi dampak lingkungan akibat menumpuknya sampah di manamana.

\section{KESIMPULAN DAN SARAN}

Hasil penelitian dapat disimpulkan bahwa Sedekah Sampah adalah salah satu 
bentuk pengelolaan sampah partisipatif yang perlu ditingkatkan mutu pelaksanaannya, Strategi yang dilakukan untuk meningkatkan partisipasi masyarakat adalah perbaikan fasilitas dan peningkatan keterlibatan tokoh masyarakat dalam mensosialisasikan dan memfasilitasi pelaksanaan program sedekah sampah, Peningkatan manfaat sedekah sampah perlu dilakukan agar masyrakat bersedia ikut secara sukarela jika telah merasakan manfaat program tersebut.

\section{DAFTAR PUSTAKA}

Antara News. 2021. KLHK: Masjid bisa berkontribusi dalam isu pengelolaan sampah. https://www.antaranews.c om/berita/2130878/klhk-masjidbisa-berkontribusi-dalam-isupengelolaan-sampah\#mobilenav [Diakses pada : 11 Agustus 2021]

Hines, J.M., Hungerford, H.R. \& Tomera, A.N. (1986-87). Analysis and synthesis of research on responsible pro-environmental behavior: a meta-analysis. The Journal of Environmental Education, 18(2), pp. 1-8.

Ismoyo, C., Muluk, K., dan Sale, C. 2012. Peningkatan Partisipasi Masyarakat dalam Pengelolaan Sampah Rumah Tangga. E-Journal Reformasi Vol. 5, No. 1, 2015.

https://jurnal.unitri.ac.id/index.php/r eformasi/article/download/65/87 .

PDF file [Diakses pada : 11 Agustus 2021]

Jamanti, R. 2014. Pengaruh Berita Banjir Di oran Kaltim Terhadap Kesadaran
Lingkungan Mayarakat Kelurahan Termindung Permai Samarinda. E Journal Ilmu Komunikasi. 2014, 2(1): 17 - 33. [Diakses pada : 11 Agustus 2021].

Kollmuss, A. \& Agyeman, J. 2002. Mind The Gap: why do people act environmentally and what are the barriers to pro-environmental behaviour? The Journal of Environmental Education Research, vol.8, No.3.

Laporan Kinerja (LKIP) Dinas Lingkungan Hidup Kota Makassar tahun 2018.

Republika. 2021 KLKH Dukung Masjid Kelola Sampah.

https://www.republika.co.id/berita/qsdhsq 483/klkh-dukung-masjid-kelolasampah [Diakses pada : 11 Agustus 2021]

Suara Sulsel. 2021. TPA Antang Mengkhawatirkan, Tumpukan Sampah Sudah Mencapai 40 Meter. https://sulsel.suara.com/read/2021/0 3/26/181616/tpa-antangmengkhawatirkan-tumpukansampah-sudah-mencapai-40meter?page $=1$ [Diakses pada : 11 Agustus 2021]

Yamin, M.N. 2019. Evaluasi Program LISA dalam MakassarTa Tidak Rantasa' di Kecamatan Rappocici Kota Makassar. Birokrat, Jurnal Ilmu Administrasi Publik, Volume 8, No. 2, Agustus 2019 